\title{
Zakat as a Local Revenue in Aceh: A Dynamics of Policy Implementation in the Local Realm
}

\author{
Dahlawi \\ Department of Government Studies, Universitas Syiah Kuala, Kota Banda Aceh, \\ Indonesia, J1. Teuku Nyak Arief No.441, Kopelma Darussalam, Kec. Syiah Kuala, \\ Aceh 23111 \\ Email: dahlawi@unsyiah.ac.id \\ Saddam Rassanjani \\ Department of Government Studies, Universitas Syiah Kuala, Kota Banda Aceh, \\ Indonesia, J1. Teuku Nyak Arief No.441, Kopelma Darussalam, Kec. Syiah Kuala, \\ Aceh 23111 \\ Email: saddam.rassanjani@unsyiah.ac.id

\section{Herizal} \\ Department of Government Studies, Universitas Syiah Kuala, Kota Banda Aceh. \\ Indonesia, Jl. Teuku Nyak Arief No.441, Kopelma Darussalam, Kec. Syiah Kuala, \\ Aceh 23111 \\ Email: herizal.ismail@unsyiah.ac.id
}

\begin{abstract}
The legitimacy given by the central government to Aceh through Law Number 11 of 2006 concerning the Aceh Government has resulted in a policy of managing Zakat as a source of regional income in Aceh by Baitul Mal Aceh (BMA). Qanun Number 10 of 2018 concerning Baitul Mal is the basis for realizing these ideals. This research tries to look at the dynamics of policy implementation in the local realm using George C. Edwards III's theory. The authors apply qualitative research to get the desired conclusion by observing and interviewing several respondents, especially those implementing the policy. In implementing Qanun Number 10 of 2018, Baitul Mal has experienced many obstacles; zakat management as local revenue cannot be implemented according to sharia regulations but must follow regional financial management guidelines. Therefore, it is necessary to make further adjustments to qanuns or derivative legal rules to make their management more optimal and follow Syar'i provisions.
\end{abstract}

Keywords: zakat; PAD; Aceh; public policy.

Zakat as a Local Revenue in Aceh: a Dynamics of Policy Implementation in the Local Realm 


\section{INTRODUCTION}

One of the tasks and functions of the regional government in the context of regional autonomy is to encourage efforts to increase Regional Original Income (PAD), where the government must be able to maximize the original regional income for the welfare and prosperity of the region. Although each area, according to the law, has received an injection of funds from various financial schemes from the central government, the existence of PAD is still encouraged and prioritized to improve regional welfare (Putra \& Ulupui, 2015; Yasa, 2015). This fact is because local governments can use PAD relatively more freely to accelerate regional interests without being too tied to the financial responsibilities of the central government.

As an area that is given the authority in matters of government administration, Aceh Province has much uniqueness, including in the case of PAD, such as making Zakat a part of PAD (Musa, 2016; Varlitya, 2017). Positively, this large authority should be an opportunity for Aceh to become a more developed region (Novialdi \& Rassanjani, 2020). Therefore, Zakat as PAD is an extraordinary breakthrough where a religious obligation is adopted into a citizen's duty, making Zakat an official source of state finances other than taxes. This unique feature for Aceh is hard to be found in other areas where Zakat is still managed privately.

In Indonesia, zakat management is regulated in Law Number 23 the Year 2011 concerning Zakat Management; several articles in the law regulate who can manage Zakat. In this case, Zakat can be controlled by anyone who wants to handle it (M. Aziz, 2014) because zakat management is also a form of worship (Atabik, 2016), as long as they are responsible for reporting zakat management to the public and authorities (Rahman, 2015). Therefore, if only certain parties are granted the right to manage Zakat, it is tantamount to violating the other party's opportunity to worship.

Unlike other regions, zakat management in Aceh is not subject to the National Zakat Management Act because Aceh has special autonomy as regulated in Law No. 11 of 2006 on Aceh Governance. The law states that Zakat is one source of income for Aceh; furthermore, Zakat, waqf, and other religious assets are managed by the Baitul Mal Aceh. The provision of Zakat as PAD in Aceh has been implemented since the enactment of Law Number 18 of 2001 concerning Special Autonomy for the Special Region of Aceh as the Province of Nanggroe Aceh Darussalam, before being reaffirmed in Law Number 11 of 2006 concerning Aceh Governance (Dahlawi et al., 2021). Then, the specific rules are regulated in Qanun Number 10 of 2007 concerning Baitul Mal, which states that all zakat receipts managed by Baitul Mal Aceh are a source of Aceh PAD be deposited in the Aceh regional general treasury.

Zakat as government revenue is not something new. Muhammad (2019) stated that Zakat in Saudi Arabia is included in state income, and its management is under the orders of the Saudi government. Furthermore, Saudi Arabia manages 
Zakat under the finance ministry, forming a special Maslahat Az-Zakat Wa AdDakhl. Hasanah (2014) stated that people who have paid Zakat were no longer subject to tax; thus, it does not create a double obligation for the payer. Zakat in Saudi Arabia is only required for Muslims, while the payment for non-Muslims is tax. That kind of scheme results in a higher proportion of zakat income than taxes (Ridwan, 2016). Thus, the management of Zakat practically increases state income. And this potential is also can be maximized for local revenue, especially PAD in Aceh.

The management of Zakat in Aceh is carried out by Baitul Mal Aceh, a regional institution, although non-structural. As previously stated, Baitul Mal's existence was initially regulated in Qanun No.10 of 2007 and then revised to Qanun No.10 of 2018. Baitul Mal Aceh administrators' appointment is like the appointment of regional agency officials because they have to go through a fit and proper test from the Aceh legislative body (DPRA) and independent institutions. In Qanun Number 10 of 2018 concerning Baitul Mal, it is explained that the Baitul Mal Aceh is a non-structural institution that functions independently but must be accountable to the Governor in its implementation.

Zakat as PAD can be considered a brilliant breakthrough, unique to Aceh and the only one in Indonesia, but it is not without serious problems. As PAD in its management, Zakat adheres to regional financial provisions, such as waiting for the Aceh Expenditure Budget (APBA). Whereas in religion, once the Zakat is collected, the committee must immediately distribute it to recipients (Adnan et al., 2019; Saad et al., 2016). So that Zakat deposited into the regional treasury becomes pure PAD is considered to have violated sharia principles; therefore, various polemic have arisen.

Zakat as PAD in its implementation has legal implications (Musa, 2016), as was done by Baitul Mal, who distributed Zakat directly to mustahik without first depositing it into the regional treasury as stipulated in pure PAD (Darma et al., 2017). The disbursement process also does not go through a bureaucratic mechanism. The realization of zakat distribution by Baitul Mal is often a finding of the Supreme Audit Agency (BPK) at the end of each year because it is not listed in the PAD report (Harianto, 2016). Ironically, it was intended for benefit, but bureaucratic rules could not be juxtaposed with religious practices.

The management of Zakat as part of PAD is considered too bureaucratic and injures the principles of zakat management, according to sharia. Zakat cannot be distributed immediately to mustahik, a religious order, because it must wait for APBA approval (Hastuti \& Redi, 2018; Musa, 2017). Until now, the status quo of Zakat as PAD is still rolling until it produces chaos. On the other hand, Baitul Mal Aceh continues to maximize the potential of zakat management as PAD. The Zakat Manager once suggested that Zakat in Aceh be treated as a special PAD, then the discourse of Zakat as a tax deduction, and various other positive things. This research focuses on implementing policies at the local level, Aceh, namely Zakat as local revenue (PAD). The specific discussion on the performance of Baitul Mal

Zakat as a Local Revenue in Aceh: a Dynamics of Policy Implementation in the Local Realm

Dahlawi Dahlawi, Saddam Rassanjani, Herizal Herizal 
in optimizing Zakat as PAD in Aceh. This research is expected to provide an overview of governance dynamics in the regions. What is presented can be input for zakat managers in Indonesia and worldwide.

\section{RESEARCH METHODS}

This type of research approach used in this research is qualitativedescriptive. Qualitative research starts from assumptions about reality or social phenomena or social interactions that are unique and complex. There are certain regularities or patterns, but they are full of variations. So the data or information in this study is traced as widely and deeply as possible through in-depth interviews so that the description of the interactions can holistically take place; the most important thing is how to find critical informants who have information following the focus of the study.

This research focuses on Aceh Government policies related to the determination of Zakat as a source of Aceh Regional Original Income (PAD) according to Law Number 11 of 2006 and its management by Baitul Mal Aceh based on Qanun Number 10 of 2018, mainly related to the existence of obstacles in managing Zakat and corrections of these constraints. Therefore, this study intends to explore various views on zakat policy as PAD and Baitul Mal as a management institution that carries out tasks according to Islamic law and does not conflict with state/regional financial provisions management. Field data will be collided with the theory of public policy implementation by George C. Edwards III.

In qualitative research, the purposive sampling technique is one of the most widely used sampling techniques. This sampling technique allows researchers to study central issues to meet the requirements of good informants, namely conveying data as it is, being honest, responsible, communicating well, and understanding the object of research.

To obtain these research results' validity is necessary do an examination technique. The implementation of the inspection technique is based on specific criteria. In qualitative research, the confirmability test is similar to the dependency test to be carried out simultaneously. Testing confirmability means testing the research results regarding the process being carried out. If the research results function, the research has met the confirmability standard. In the study, do not let the process not exist, but the results are there. According to the degree of certainty (confirmability) criterion, the inspection technique is to audit the confidence of research results.

\section{RESULTS AND DISCUSSION}

This section consists of results and discussion. Sufficient data should support every effect. Then, the result should answer the research question or hypothesis stated earlier in the introduction. The zakat management in Aceh is closely related to the Baitul Mal Aceh (BMA) existence. An informant with the 
initials UMI stated that Baitul Mal was a legal amil zakat body in Aceh under Qanun Number 10 of 2007, which was later revised to Qanun Number 10 of 2018; this particular institution was given full responsibility in terms of managing Zakat in Aceh. UMI added determination of BMA as the manager of the Zakat in Aceh was influenced by many parties, such as the role of Acehnese Ulama, elements of society, and the government itself. UMI also stated,

The basis for determining the Baitul Mal Aceh is a special provision for this region because it has implemented Islamic law. Due to the large number of community funds that have not been accommodated so far, a particular institution is formed to care for Zakat, infaq, sadaqah, and other religious assets (UMI/W/FK/I).

Meanwhile, an informant with the initials HEN said that Aceh's Baitul Mal was constrained by legal regulations (Qanun Aceh, 2018). An informant also expressed the same thing with the initials AMR who added that "the initial legal rules were internal factors that hindered Baitul Mal's performance in managing zakat." He further stated that there were several fundamental weaknesses in BMA when it was still guided by Aceh Qanun Number 10 of 2007, including:

(i) There is no consistency and harmonization between one article and another; (ii) Baitul Mal as a zakat management organization and non-bank financial institutions is not supported by a commissariat institution that can provide legal advocacy and supervision; (iii) The organizational structure at Baitul Mal is not following the needs of the organization, making it challenging to implement; (iv) The Baitul Mal Qanun regulates in detail the requirements and the fit and proper test mechanism for the candidate for leadership of the Baitul Mal Aceh. These requirements are more severe than the requirements for structural positions at the regional level. (v) On the other hand, the role of the Head of Baitul Mal is non-structural, so that he is not entitled to work performance allowances. The salary is also inadequate compared to his responsibilities and positions, which are equivalent to the leadership of other Aceh particular institutions. (vi) There are no restrictions on the working period for Baitul Mal managers, resulting in unhealthy conditions for the amil institutions that manage Zakat (AMR/W/FK/I).

These non-ideal working conditions have been improved by revising legal regulations, namely by issuing Qanun Number 10 of 2018. In its journey of implementing zakat management policies as local revenue, of course, BMA has experienced all kinds of dynamics that deserve to be analyzed. Several informants in this study have clearly stated the problems in BMA. Some of these problems can be seen in more detail if linked to George C. Edwards III's theory of policy implementation in Ramdhani and Ramdhani (2017), which stated that four variables influence policy implementation; bureaucratic structure, resources, disposition, and communication.

Zakat as a Local Revenue in Aceh: a Dynamics of Policy Implementation in the Local Realm Dahlawi Dahlawi, Saddam Rassanjani, Herizal Herizal 


\section{Bureaucratic Structure}

Long before Baitul Mal Aceh was born, the implementation of Zakat was managed by mosques. El Ayyubi and Saputri (2018) stated that mosques had been the oldest zakat distribution institutions in Indonesia since Islam entered the archipelago. The mosque's minimal scope constrains zakat management in mosques; usually, the collection and distribution of Zakat are limited to the village community around the mosque. One mosque can collect a tremendous amount of Zakat, while the distribution is limited to the mosque area. Whereas in other mosques, the amount of Zakat collected is minimal, so it is not sufficient for the existing community's needs; thus, the distribution of Zakat is not evenly distributed.

With the formation of the BMA, it is hoped that the management of Zakat can be better organized because one of the goals of the existence of the BMA is to make the distribution of Zakat more even and not accumulate in one area so that the existence of Zakat can realize economic equality. However, the formation of BMA can lead to conflicts of interest between groups or between Islamic organizations. For example, establishing a zakat collection unit at the village or sub-district level excludes the mosque, previously a zakat management institution. In other words, the formation of BMA as a zakat management institution causes other parties to feel worried and disturbed by their interests.

BMA builds relationships with various related matters in carrying out its duties and authorities. The implementation involves associated issues, one of which is the need to elaborate on these rules in guidelines or implementing practices (SOP). Indeed, many SOPs have been prepared, but given the limited human resources, time, costs, and other facilities, priorities are determined for their completion. An informant with the initials SMH said that "in implementing zakat management in Baitul Mal, the implementation instructions are incomplete because it is still in the preparation process." This was also conveyed by SYAM, Head of Legal and Public Relations Division; He explained, in the implementation of zakat management activities, reliable work procedures are needed, most of which already have, although institutionally it is not yet a single unit." HEN added that "SOPs for some work fields need great attention to work by responsibilities." The incomplete SOP needs to be improved by Baitul Mal Aceh to facilitate the implementation and supervision of the programs and activities that have been determined.

Talking about authority, the Head of Baitul Mal Aceh can determine the rules for zakat utilization. However, because Zakat is included as PAD and deposited in a special account, problems arise regarding its utilization. As is known, the use of the APBD is regulated in the discussion of the Aceh Regional Revenue and Expenditure Budget (APBA), so if there are other urgent matters and require zakat funds to be immediately allocated, it will certainly be a problem in the future, especially when the BMA wants to provide funds beyond those already provided. They are issued and regulated in the APBA. The mechanism for zakat entry into PAD is the same as the tax mechanism. All incoming funds are collected first into 
the local government treasury for one calendar year, then can only be used after approval by the government for distribution in the following year. SMH said:

For now, Zakat as part of PAD follows the provisions of state finances. However, Baitul Mal Aceh has tried to lobby the government since 2010 to give special treatment to zakat management, which can be directly distributed to the poor without waiting for the APBA approval process. And this will continue to be pursued until it is finally realized (SMH/W/FP/E).

Besides, the performance of the Baitul Mal also experienced problems that came from external Baitul Mal. One of them is the dominant influence of Dayah ulama, who disagree with the policies taken by Baitul Mal. For the people of Aceh, the cleric is a figure entrusted with providing direction in various aspects of life, and political and government affairs are also taken into account (Muntasir \& Aminullah, 2020; Nasution \& Miswari, 2019; Nazim et al., 2018). The difference of opinion between the ulama and the BMA causes the program realization to be not optimal. SMH argued that socialization activities arose from the ulama on several occasions, such as why Zakat should be recorded first as PAD and whether holy Zakat will not be mixed with other PAD sources are sometimes still sincere. How do BMA and its staff regulate Zakat's liquidity because the mechanism for disbursing zakat funds is very bureaucratic? The chairman of PW NU Aceh asked for the provisions of Zakat as PAD to be amended. AMR stated:

The existence of the principle of Dayah Ulama or Pesantren becomes an obstacle and influences the community's decision to pay Zakat independently and not through the Baitul Mal. Regarding the determination of Zakat as PAD, some Dayah scholars have expressed their disagreement directly with the Baitul Mal Aceh (AMR/W/FK/E).

SMH also conveyed the same thing; namely, Dayah scholars still do not agree with Zakat on income or Zakat on the profession. But certainly, Baitul Mal Aceh continues to coordinate intensively with related parties, even though it cannot be said that it is perfect. Likewise, other Implementing Agency officials, CUT and RIZ, believe that work coordination has been carried out internally and externally.

\section{Resources}

Baitul Mal Acehas, a formal organization in charge of managing Zakat, waqf, and other religious assets, must undoubtedly be led by a visionary leader. Mascareño (2020) stated that an innovative leader could persuade others to contribute to future realization. Because leaders are the leading resource and central point of every activity in an organization, a manager must prioritize duties, responsibilities and foster harmonious relationships, both with superiors and subordinates. Furthermore, Nwachukwu (2017) assume that a leader who focuses on achieving a vision or mission will inspire and empower his followers to face organizational change and growth. Therefore, leaders as managers are responsible

Zakat as a Local Revenue in Aceh: a Dynamics of Policy Implementation in the Local Realm Dahlawi Dahlawi, Saddam Rassanjani, Herizal Herizal 
for directing the picture and resources to produce the most effective and efficient things.

The Secretary of BMA stated that, from time to time, Baitul Mal Aceh was led by a figure of high quality. Even the chairman of the 4th BMA is an expert in Zakat, has a doctorate in Zakat, is a lecturer at UIN Ar-Raniry Banda Aceh, and his experience before leading Baitul Mal Aceh was serving as Regent of Baitul Mal Aceh Besar. Here, it can be seen that having experienced and qualified leaders are well aware of BMA. Thus, this is the organizational strength of the Baitul Mal, which will facilitate the organization's continuity in achieving its goals.

Regarding the apparatus resources, RIZ said that the BMA apparatus was sufficient in terms of quantity, but it needed to be fixed and improved in terms of quality. The same thing was conveyed by CUT, the Head of the Finance Section of the Baitul Mal Aceh Secretariat, that the Baitul Mal Aceh apparatus was sufficient in terms of quantity. Still, it needed to be fixed and improved according to competence; sometimes, they did not understand their main tasks and functions, even though their respective duties and authorities were there is. Sintiawati (2017) argued that quality must be balanced to produce better work results, especially related to tasks under the given responsibilities. Therefore, increasing the apparatus's capacity must be carried out so that existing human resources are not wasted; moreover, they work and are paid by the state through public taxes.

Regarding operations, funds or budgets determine the success of an activity. In this case, the funds required for operations are highly dependent on the funds allocated by the local government. Erlina and Muda (2017) stated that a budget is needed to manage resources properly to achieve the planned program's goals. The good news is that there has been an allocation of funds from the government, which is devoted to zakat management, closely related to the political will of the local government. Some regional leaders in Aceh's political will in implementing Islamic law are very high, including Zakat as one of them (Fahmi \& Haryanto, 2020). The management of Zakat has become a priority of the Aceh Government. A special allocation of funds for zakat management has been provided, and even the Baitul Mal Aceh Secretariat has become one of the regional apparatus. Therefore, it is undeniable that in the professional management of Zakat, it is necessary to have adequate funds to support activities to be more transparent, accountable, and follow statutory provisions.

Meanwhile, in implementing zakat management, the placement of officials or staff in Baitul Mal Aceh has relatively not met the requirements required in Qanun Number 10 of 2018. The achievement of performance has not been maximal. Some employees are fully supportive and dedicated to working for Baitul Mal Aceh's advancement to alleviate poverty. Still, some work because they are placed in the Baitul Mal without their wish, so their work motivation is almost non-existent even though they come to the office every day. Gautama So (2018) stated that employee motivation to work affects their performance to affect the organization's performance. Conditions in Baitul Mal's body become inefficient, thus slowing the 
achievement of organizational goals. Therefore, before the employees' placement, determine the criteria for filling existing vacancies/formations.

Regarding facilities and infrastructure, BMA continues to improve; the lack of workspace has been added; insufficient official vehicles are now adequate; the slow internet network to support online zakat services has gradually become very stable. Pratiwi (2019) view that good work facilities with well-maintained conditions will help smooth work processes in an organization. SMH admitted that minimal facilities, in the beginning, constrained BMA's performance. Still, these constraints have gradually begun to be resolved for the last five years. The replacement of goods and services procurement officials was allegedly the main supporting factor in improving BMA's performance in facilities and infrastructure. It must be admitted that in terms of facilities and infrastructure, BMA is very good and complete; support from various related parties is important moral assistance for Baitul Mal Aceh's construction.

\section{Disposition}

If we look further in the implementation of zakat management, especially zakat distribution, it turns out that there are still many obstacles. Although the Baitul Mal Aceh work areas are Banda Aceh and Aceh Besar, coordination is carried out to the villages where Zakat is handed over. This is done to find out directly the condition of the Zakat. Conveyed by AMR, the former Chairman of Baitul Mal Aceh, that Baitul Mal Aceh in zakat management always coordinates work internally.

However, it turns out that there is still a fragmentation of the main tasks of the Baitul Mal with the main functions of the Baitul Mal Secretariat. Because the Head of the Baitul Mal Secretariat is appointed as an official who assesses the work of budget users, goods users, and civil servants in echelon 2B structural positions, coordination, integration, synchronization, simplification with the Baitul Mal Head are often neglected. Non-structural Baitul Mal is considered as contract employees. Likewise, Baitul Mal Aceh happened, it is necessary to improve work coordination to achieve more optimal and efficient zakat management.

It turns out that the worker's motivation factor also influences the implementation of Zakat as PAD in Aceh. Not all Baitul Mal Aceh officials have good work motivation because those placed in these institutions are generally not informed beforehand. That way, not all parties can understand the rules and their derivatives regarding Zakat and Qanun Number 10 of 2018; it is necessary to carry out continuous socialization to understand Zakat PAD and Baitul Mal regulations administrators. (ADE/W/FK/I)

Another problem is the emergence of a hopeful work attitude due to the lack of coordination between Baitul Mal Aceh personnel; this can be commonplace for young organizations. The solution to the problem of coordination in organizations is competent managers' existence (Bouty \& Drucker-Godard, 2019). Therefore, this

Zakat as a Local Revenue in Aceh: a Dynamics of Policy Implementation in the Local Realm

Dahlawi Dahlawi, Saddam Rassanjani, Herizal Herizal 
problem is only a matter of time to solve, considering that BMA is still in the process of organizational maturity. Meanwhile, SMH stated that skilled personnel with the same vision as the organization worked according to expectations; on the other hand, those less skilled had worse results, especially not having an idea and different interests. According to MD, the former Head of Baitul Mal Aceh, "Baitul Mal personnel must be individuals who live their role as amil because the quality of amil will determine the quality and effectiveness of managing zakat funds."

Improvements in employees' quality need to be done to run effectively, so it needs to do a job analysis, job descriptions, and job specifications. Because through job analysis mapping, people who match the organization's needs can be drawn (Kristanto et al., 2014). With job analysis, job descriptions, and job specifications, it is possible to determine the number of employees required and qualifications. Then the employee development is carried out to increase efficiency and effectiveness.

In terms of applicable provisions, there are differences between the national laws and regulations in Aceh, both in the form of Qanuns, Governor Regulations, Governor Instruction, and other rules as implementation rules. According to SMH, the Head of Socialization and Development of Baitul Mal Aceh, the initial story of Zakat as part of Regional Original Income (PAD) in Aceh is contained in Law Number 18 of 2001 and article 180 of Law Number 11 of 2006, and this provision is unknown in other regions throughout Indonesia. Problems also arise because in every examination by the Supreme Audit Agency (BPK) or the Aceh Inspectorate, Zakat as PAD remains questionable. Regarding the zakat audit by the BPK, a positive view was expressed by Subekan (2016), where he assessed that the audit of zakat management by the BPK would strengthen the transparency and accountability of zakat management so that people have greater trust in zakat management institutions.

According to ALY, the Chairperson of the Baitul Mal Aceh Sharia Advisory Council, the provisions of Zakat as PAD complement the requirements of Zakat, which can reduce the payable income tax under Article 192 of Law Number 11 of 2006. This has been attempted but unsuccessful because it is deemed contrary to the applicable national income tax law. Besides, if Zakat has been recognized as a tax deduction, the implication is that State / Regional revenues will decrease. In its implementation, this raises problems because Zakat as PAD must still be exempted from existing financial provisions. On the one hand, the management of Zakat as an Islamic law must remain independent, by the provisions of Islamic law, and must be distributed to eight asnaf (Rosli et al., 2017; Takril \& Othman, 2020).

furthermore, it must also pay attention to regional financial provisions. (Hastuti \& Redi, 2018). This means that zakat management must comply with regional financial management regulations and mechanisms that need to be made into a special PAD so that its management is more flexible. 


\section{Jurnal Ilmiah Al-Syir'ah Vol. 19, No. 2 (2021): 200-217 \\ Website: http://journal.iain-manado.ac.id/index.php/JIS ISSN 2528-0368 (online) ISSN 1693-4202 (print)}

The regional financial mechanism is an obstacle for one example of zakat distribution activities. Certain regencies/cities are required to tender for the distribution of zakat funds to purchase three-wheeled bicycles for zakat recipients (mustahik). Zakat issued from the regional general treasury is treated as a grant fund. Zakat that has been paid cannot be fully withdrawn. Zakat is taken from the treasurer, not from the source of Zakat, but Zakat's other sources. Withdrawal of Zakat must wait for the approval of the APBA, which is often late, causing several other problems.

\section{Communication}

With the ability to understand the parties involved in zakat management, the leadership of Baitul Mal Aceh must have a clear vision so that they know what, how, and where Baitul Mal Aceh is to develop. Therefore, everyone understands the duties, authorities, and responsibilities of the various rules and descriptions, as previously mentioned. It needs to be socialized on an ongoing basis. If there are obstacles and require adjustments or require policies to facilitate implementation and achieving goals, it will be easier. Internally, there are no significant communication problems that can hinder the performance of the Baitul Mal. However, externally, the lack of coordination with parties outside Aceh government agencies is an inhibiting factor. As conveyed by UMI who said:

External factors that hinder Baitul Mal's performance are some people who are still reluctant to pay Zakat to Baitul Mal for several reasons, such as lack of understanding and wanting to give Zakat directly Mustahiq. Regarding the desire to provide Zakat now to Mustahiq, it is also related to the influence of the Dayah Ulama or Islamic boarding schools, some of which have not agreed to determine income zakat's obligation. (UMI/W/FK/E)

HEN also stated that "some people still think that income zakat is not compulsory, and prefer to distribute zakat privately." Several previous studies have also revealed that the level of public trust in zakat managers is still low (Aziz \& Susetyo, 2020; Istikhomah \& Asrori, 2019; Syafiq, 2017; Wardhani, 2018), even though the collection and distribution of Zakat will be more optimal if done through zakat institutions (Lubis \& Azizah, 2018). In responding to people's lack of trust in zakat management organizations, each of these organizations needs to implement an open reporting system published and accessed by all parties. Rachman and Salam (2018) recommend financial technology (fintech) as an innovation that needs to be adapted by zakat managers to increase the effectiveness and efficiency of financial management to increase public trust in zakat managers. Bachtiar (2020) also strengthened this offer, which assessed the digital bureaucracy as a platform that can open up opportunities for improving institutional performance and open the broadest possible opportunity for the public to participate in it. With the application of the open reporting system as suggested, it is hoped that the public's suspicion of fraud committed by the administrators of the Zakat Collection Unit or Baitul Mal will decrease, and the enthusiasm of the community to deposit Zakat via zakat managers will increase.

Zakat as a Local Revenue in Aceh: a Dynamics of Policy Implementation in the Local Realm

Dahlawi Dahlawi, Saddam Rassanjani, Herizal Herizal 
Meanwhile, for the sake of strengthening institutional performance, several parties need to be involved in improving the performance of Baitul Mal Aceh in managing Zakat in the future, namely by establishing cooperative relationships with several parties such as the Aceh Financial Management Agency, Employers' Organizations, Director General of Taxes and Central government.

The Aceh Financial Management Agency must collect Zakat directly from the relevant agencies, employers' organizations participate in socializing Zakat collection through the Baitul Mal. The Director-General of Taxes supports the implementation of Zakat as a tax deduction, and the central government supports the display of Zakat from vertical agencies and large companies. $(\mathrm{SMH} / \mathrm{W} / \mathrm{FP} / \mathrm{E})$

Suppose the concept of Zakat applied in Aceh currently refers to zakat management in Saudi Arabia. In that case, something that needs to be known, namely the zakat management in Saudi Arabia, is an inseparable part of state revenue (Muhammad, 2019). Its use is also for state matters, such as the tax concept in general. Then, the parties who have paid Zakat will not be taxed to avoid double taxation (Hasanah, 2014). If the idea of Zakat is part of PAD, there should be a new mechanism whereby parties who have paid Zakat can become part of the deduction of paying taxes. Then the object of zakat realization must be transparent, whether it is for the mustahiq (generally the concept of Zakat) or the use of zakat funds can be expanded its meaning as part of regional income be used for regional needs.

Talking about taxes levied by the state, (Tarmizi, 2019) reveals that taxes have been abolished in Islam. However, almost all Muslim-majority countries still collect taxes to finance state administration needs. If taxes are not enforced, it will be difficult for the state to carry out its affairs and needs (Andrianto, 2019; Siregar, 2017), especially various matters that regulate many people's lives. Hasan (2018) views taxes as another levy outside of Zakat, which is allowed because it follows the "maslahah mursalah" principle, as long as it is managed professionally and ensures the nation's economic progress, taxes are deemed necessary. It is also supported by (Hidayatulloh, 2019), who considers Zakat and taxes to play an essential role in the country's economy and solves problems on a micro level while taxes solve issues on a macro level.

The purpose of taxes and Zakat is the same, namely as a source of funds to realize the welfare of the state and society. They are using taxes to finance activities in development and distributing Zakat to the poor who are expected to support their economic life to increase the national economic development index. Therefore, differences of opinion regarding taxes in some circles of society need to be communicated and straightened out by BMA and religious experts. The administration of state levies can help support the sustainability of Zakat. 


\section{Opportunities and Challenges}

As a new institution with a new policy, Baitul Mal Aceh's presence is a breakthrough from the Aceh government. The Zakat potential in Acehnese society can be collected more optimally and managed according to sharia. However, this step requires time, effort, and consistent thought to make it happen. Given the development of zakat management growing and increasing, BMA must foster trust in the community.

Many studies have seen Zakat as a potential instrument in reducing poverty (Arif, 2017; Miah, 2019; Rassanjani, 2018). Sadly, Aceh has become the poorest province in Sumatra (BPS, 2019, 2020, 2021). The challenges of poverty alleviation are getting more challenging amid the COVID-19 pandemic; however, Rassanjani (2021) saw Zakat as a sustainable source of funds capable of being an alternative source of funding in poverty alleviation efforts amid sluggish economic activity. Therefore, the specialty of managing Zakat as PAD should be optimized by the Aceh government to increase development and reduce poverty.

There are several things that the Aceh government needs to consider regarding the improvement of zakat management, such as revising the rules so that they can suit their needs, as stated by $\mathrm{SMH}$, the Head of Socialization and Development, that Qanun Number 10 of 2018 needs to accommodate several things, namely: (i) simplification of the organizational structure; (ii) completing arrangements regarding waqf; (iii) collection of Zakat from vertical agencies; (iv), and (v) CSR funds. Furthermore, as a solution to the problem of Zakat as PAD, there needs to be some special treatment, for example, (i) zakat can be disbursed before the APBA is passed; (ii) zakat that exceeds the target income can be withdrawn entirely; (iii) withdrawal of Zakat refers to the latest data approved by the Sharia Advisory Board; (iv) the remaining Zakat from last year can be withdrawn in the following year; (v) the liability for Zakat does not refer to the fiscal year; and (vi) several other exemptions from the financial regulations that apply nationally.

Coordination of work with regional and vertical government agencies in Aceh must continue to support zakat collection and its management by the Baitul Mal. The parties involved, such as the Aceh Financial Management Agency, must collect Zakat directly from the relevant agencies. The Director-General of Taxes must support the implementation of Zakat as a tax deduction. Also, concrete steps are needed in its performance, through (i) strengthening regulations, (ii) strengthening people's understanding, (iii) placing human resources according to competencies, and (iv) among Baitul Mal, DPR Aceh, Inspectorate Aceh, and BPK must have the same perception in understanding Zakat as PAD.

The abovementioned factors hope to make Baitul Mal Aceh play an optimal and professional role. The current condition has passed the initial foundation phase, and now is the era of professional, institutional development with information technology systems. Working relationships with other agencies have been

Zakat as a Local Revenue in Aceh: a Dynamics of Policy Implementation in the Local Realm

Dahlawi Dahlawi, Saddam Rassanjani, Herizal Herizal 
established; this can be seen by increasing zakat fund income every year. Because Zakat as PAD has high legitimacy in law, there is nothing wrong with the Aceh government being more proactive in managing Zakat. As a regional policy whose enactment has become part of the agency's function, it is necessary to supervise the policy's implementation; in this case, the Baitul Mal Aceh must strengthen coordination with related agencies.

\section{CONCLUSION}

This study examines Zakat as PAD using the theory of public policy implementation developed by George W. Edwards III, who mentioned four factors or variables influencing policy implementation: bureaucratic authority or structure, resources, disposition or attitude of the implementer, and communication.

Based on the description of the results of this study, the researcher proposes that Baitul Mal Aceh pays attention to aspects of disposition comprehensively; This can be seen in the interaction pattern of officials working at Baitul Mal Aceh. Then, it is also necessary to build intensive communication with other parties, especially other agencies in Aceh, to increase zakat income. The strength of zakat funds as PAD is very much needed for regional development. If stakeholders can manage Zakat more optimally, then the source of public financial funds will become a sustainable source of funds. And at any time, it can be an alternative for special autonomy funds, which are currently running low and cannot be extended by the central government.

Therefore, the role of the Aceh government as a policymaker must always be consistent in supporting the implementation of Qanun No. 10 of 2018 concerning Baitul Mal so that the management of Zakat as regional revenue can be more optimal. In addition, other derivative policies are needed to make Baitul Mal Aceh a professional and trustworthy institution in managing Zakat in Aceh. And Baitul Mal Aceh needs to be supported by granting full authority by the Aceh government in managing zakat funds, waqf assets, and other religious assets for the benefit of the people and being the front line according to Islamic law.

\section{ACKNOWLEDGMENTS}

Researcher thank to all parties involved in the preparation of this paper, especially the Baitul Mal Aceh who were very cooperative in serving the needs of the authors in this study. 


\section{REFERENCES}

Adnan, N. I. M., Kashim, M. I. A., Mohd Hamat, Z., Adnan, H. M., Adnan, I. M., \& Sham, F. M. (2019). The potential for implementing microfinancing from the zakat fund in malaysia. Humanities \& Social Sciences Reviews, 7(4), 542548.

Andrianto, A. (2019). Studi Terhadap Peran Etika Pengelolaan Pajak Menurut Islam. Majalah Ekonomi, 24(1), 12-22.

Arif, M. (2017). Zakat as a mode of poverty alleviation. Asian Journal of Multidisciplinary Studies, 5(11), 57-65.

Atabik, A. (2016). Manajemen pengelolaan zakat yang Efektif di Era Kontemporer. ZISWAF: Jurnal Zakat Dan Wakaf, 2(1), 40-62.

Aziz, M. (2014). Regulasi zakat di Indonesia; Upaya menuju Pengelolaan zakat yang Profesional. Al Hikmah: Jurnal Studi Keislaman, 4(1), 2.

Aziz, M. I. A., \& Susetyo, H. (2020). Dinamika Pengelolaan Zakat Oleh Negara Di Beberapa Provinsi Di Indonesia Pasca Undang-Undang Nomor 23 Tahun 2011. Jurnal Hukum \& Pembangunan, 49(4), 968-977.

Bachtiar, R., Pramesti, D. L. D., Pratiwi, H. E., \& Saniyyah, N. (2020). Birokrasi Digital: Studi Tentang Partisipasi dan Kesiapan Masyarakat. Journal of Governance and Social Policy, 1(2), 104-129.

Bouty, I., \& Drucker-Godard, C. (2019). Managerial work and coordination: A practice-based approach onboard a racing sailboat. Human Relations, 72(3), 565-587.

BPS. (2019). Persentase Penduduk Miskin Pada September 2018 Sebesar 9,66 Persen. Badan Pusat Statistik. https://www.bps.go.id/pressrelease/2019/01/15/1549/persentase-pendudukmiskin-pada-september-2018-sebesar-9-66-persen.html

BPS. (2020). Persentase Penduduk Miskin September 2019 turun menjadi 9,22 persen. Badan Pusat Statistik.

BPS. (2021). Persentase Penduduk Miskin September 2020 naik menjadi 10,19 persen.

Badan

Pusat

Statistik. https://www.bps.go.id/pressrelease/2019/01/15/1549/persentase-pendudukmiskin-pada-september-2018-sebesar-9-66-persen.html

Dahlawi, D., Herizal, H., \& Rassanjani, S. (2021). Realisasi Zakat Sebagai Sumber Pendapatan Asli Daerah di Propinsi Aceh. NUANSA: Jurnal Penelitian Ilmu Sosial Dan Keagamaan Islam, 18(1), 86-105.

Darma, S., Sarong, H., \& Jauhari, I. (2017). Kewenangan Baitul Mal Aceh dalam Pendistribusian Zakat. Kanun Jurnal Ilmu Hukum, 19(2), 193-214.

El Ayyubi, S., \& Saputri, H. E. (2018). Analysis of the Impact of Zakat, Infak, and Sadaqah Distribution on Poverty Alleviation Based on the CIBEST Model (Case Study: Jogokariyan Baitul Maal Mosque, Yogyakarta). International Journal of Zakat, 3(2), 85-97.

Erlina, A. S., \& Muda, I. (2017). Antecedents of Budget Quality Empirical Evidence from Provincial Government In Indonesia. International Journal of Economic Research, 14(12), 301-312. 
Fahmi, R., \& Haryanto, H. (2020). Pendayagunaan Kekuasaan Pemerintah Kota Banda Aceh Era Illiza Sa'aduddin Djamal Dalam Mewujudkan Kota Madani. Journal of Governance and Social Policy, 1(2), 86-103.

Gautama So, I., Djunggara, A. A., Fahrobi, R., Simamora, B. H., Ruangkanjanases, A., \& others. (2018). Effect of Organisational Communication and Culture on Employee Motivation and Its Impact on Employee Performance. Pertanika Journal of Social Sciences \& Humanities, 26(2).

Harianto, S. (2016). Accounting For Zakat On Income Critical Study Based On Government Regulation (Case Study In Aceh Province Of Indonesia). International Journal of Business, Accounting and Management, 1(3), 47-52.

Hasan, N. I. (2018). Tinjauan Penerapan Pungutan Pajak Dan Zakat Menurut Konsep Ekonomi Islam DI Indonesia. Islamadina: Jurnal Pemikiran Islam, 19(2), 75-91.

Hasanah, U. (2014). Zakah Management in Saudi Arabia, Sudan and Indonesia. Indonesian Management and Accounting Research, 13(1), 40-61.

Hastuti, R. T., \& Redi, A. (2018). Pelaksanaan Penyaluran Zakat Oleh Baitul Mal Aceh Sebagai Pendapatan Asli Daerah Dalam Undang-Undang Nomor 11 Tahun 2006 Tentang Pemerintahan Aceh. Jurnal Hukum Adigama, 1(1), 1189-1211.

Hidayatulloh, M. H. (2019). Peran zakat dan pajak dalam menyelesaikan masalah perekonomian Indonesia. Al-Huquq: Journal of Indonesian Islamic Economic Law, 1(2), 102-121.

Istikhomah, D., \& Asrori, A. (2019). Pengaruh literasi terhadap kepercayaan muzaki pada lembaga pengelola zakat dengan akuntabilitas dan transparansi sebagai variabel intervening. Economic Education Analysis Journal, 8(1), 95109.

Kristanto, I. H., Muluk, M. R. K., \& Setyowati, E. (2014). Perencanaan Sumberdaya Aparatur melalui Analisa Jabatan dan Analisa Beban Kerja Berbasis Teknologi Informasi dalam rangka Pemetaan Jabatan. Wacana Journal of Social and Humanity Studies, 17(4), 214-223.

Lubis, M., \& Azizah, A. H. (2018). Towards achieving the efficiency in zakat management system: interaction design for optimization in Indonesia. International Conference on User Science and Engineering, 289-301.

Mascareño, J., Rietzschel, E., \& Wisse, B. (2020). Envisioning innovation: Does visionary leadership engender team innovative performance through goal alignment? Creativity and Innovation Management, 29(1), 33-48.

Miah, A. A. (2019). Integration of Zakat and Awaqf for Poverty Alleviation and Development. In Revitalization of Waqf for Socio-Economic Development, Volume I (pp. 215-242). Springer.

Muhammad, I. (2019). Analysis of Zakat System in high-income Islamic countries. The Journal of Muamalat and Islamic Finance Research, 16(2), 1-11.

Muntasir, M., \& Aminullah, M. (2020). From the Religious Stage to the Political Stage: Teungku Dayah's Political Communication Study in Aceh. Al-Balagh: Jurnal Dakwah Dan Komunikasi, 5(1), 95-116.

Musa, A. (2016). Zakat sebagai Pendapatan Asli Daerah dalam Undang-Undang Pemerintahan Aceh. Kanun Jurnal Ilmu Hukum, 18(3), 403-415. 
Musa, A. (2017). Kontribusi Pemerintah dalam Pengelolaan Zakat di Aceh (Kontestasi Penerapan Asas Lex Specialis dan Lex Generalis). Media Syari'ah: Wahana Kajian Hukum Islam Dan Pranata Sosial, 16(2), 347-370.

Nasution, I. F. A., \& Miswari. (2019). Al-ULama Warathal Al-Anbiya: Modernity and Nurture of Authority in Aceh Society. Jurnal Theologia, 30(2), 197-216.

Nazim, Y., Mohamad, M. Z., Omar, S. H. S., Wan, W. I., Abdullah, E. I. E. W. Z., Yusof, S., Maifizar, A., \& Kasim, F. M. (2018). The Role of Tasawwuf Ulama in the Governance of Aceh. International Journal of Academic Research in Business and Social Sciences, 8(10).

Novialdi, R., \& Rassanjani, S. (2020). Optimizing the Ability of Aceh Province in Paradiplomacy Practice. Nation State: Journal of International Studies, 3(1), 19-32.

Nwachukwu, C., Chladkova, H., Zufan, P., \& Olatunji, F. (2017). Visionary leadership and its relationship to corporate social performance. Imperial Journal of Interdisciplinary Research, 3(4), 1302-1311.

Pratiwi, N. J., Jamaluddin, J., Niswaty, R., \& Salam, R. (2019). The Influence of Work Facilities on Employee Performance at the Regional Financial Management Agency Secretariat Section of South Sulawesi Province. Jurnal Ad'ministrare, 6(1), 35-44.

Putra, P. G. M., \& Ulupui, I. (2015). Pendapatan Asli Daerah, Dana Alokasi Umum, Dana Alokasi Khusus, Untuk Meningkatkan Indeks Pembangunan Manusia. E-Jurnal Akuntansi Universitas Udayana, 11(2015), 863-877.

Qanun Aceh. (2018). Qanun Aceh Nomor 10 Tahun 2018 Tentang Baitul Mal (Patent No. 10). Lembaran Aceh Tahun 2018 Nomor 7.

Rachman, M. A., \& Salam, A. N. (2018). The Reinforcement of Zakat Management through Financial Technology Systems. International Journal of Zakat, 3(1), $57-69$.

Rahman, T. (2015). Akuntansi Zakat, Infak dan Sedekah (PSAK 109): Upaya Peningkatan Transparansi dan Akuntabilitas Organisasi Pengelola Zakat (OPZ). Muqtasid: Jurnal Ekonomi Dan Perbankan Syariah, 6(1), 141-164.

Ramdhani, A., \& Ramdhani, M. A. (2017). Konsep umum pelaksanaan kebijakan publik. Jurnal Publik, 11(1), 1-12.

Rassanjani, S. (2018). Ending Poverty: Factors That Might Influence the Achievement of Sustainable Development Goals (SDGs) in Indonesia. Journal of Public Administration and Governance, 8(3), 114-128.

Rassanjani, S., Risky, N., Maz, D., Alqarni, W., \& Tharis, M. A. (2021). Impact of COVID-19 on Economic Activities and Poverty Threats in the Asia-Pacific Region. Policy \& Governance Review, 5(1), 82-96.

Ridwan, M. (2016). Zakat Vs Pajak: Studi Perbandingan di Beberapa Negara Muslim. ZISWAF: Jurnal Zakat Dan Wakaf, 1(1), 1-22.

Rosli, M., Salamon, H., Muhamad, N. H. N., Zulkifli, A. H., \& Ahmad, S. M. S. (2017). Modification of Zakat Distribution Management for Muslim Community Well-Being. International Journal of Academic Research in Business and Social Sciences, 7(12), 1257-1264. 
Saad, R. A. J., Sawandi, N., \& Mohammad, R. (2016). Zakat surplus funds management. International Journal of Economics and Financial Issues, 6(7), $171-176$.

Sintiawati, N. (2017). Contribution and Training Effect for Social Worker. 3rd NFE Conference on Lifelong Learning (NFE 2016), 125-127.

Siregar, L. H. (2017). Pengampunan Pajak (Tax Amnesty) Sebagai Upaya Peningkatan Pendapatan Nasional Dari Sektor Fiskal. Hijri, 6(1).

Subekan, A. (2016). Potensi Zakat Menjadi Bagian Keuangan Negara (Studi Analisis Regulasi Kemungkinan Masuknya Zakat Menjadi Bagian dari Penerimaan dan Pengeluaran Negara). Jurisdictie, 7(2), 105-126.

Syafiq, A. (2017). Urgensi Peningkatan Akuntabilitas Lembaga Pengelola Zakat. ZISWAF: Jurnal Zakat Dan Wakaf, 3(1), 18-39.

Takril, N. F., \& Othman, N. F. (2020). Effectiveness of Zakat Collection and Distribution of Zakat counter at higher learning Institutions. International Journal of Islamic Economics and Finance Research, 3(2), 91-106.

Tarmizi, E. (2019). Harta Haram Muamalat Kontemporer. BMI Publishing.

Varlitya, C. R. (2017). Analisis Zakat Sebagai Pendapatan Asli Daerah Terhadap Indeks Pembangunan Manusia: Pendekatan Data Panel (Studi Kasus 12 Kabupaten/Kota Provinsi Aceh). Jurnal Ekonomi Dan Kebijakan Publik Indonesia, 4(2), 192-211.

Wardhani, R. W. K. (2018). Manajemen Komunikasi Badan Amil Zakat Nasional (BAZNAS) Provinsi Jawa Barat. NALAR: Jurnal Peradaban Dan Pemikiran Islam, 2(1), 12-21.

Yasa, I. N. M. (2015). Pengaruh jumlah kunjungan wisatawan, lama tinggal wisatawan dan tingkat hunian hotel terhadap Pendapatan Asli Daerah dan kesejahteraan masyarakat pada Kabupaten/Kota di Provinsi Bali. E-Jurnal Ekonomi Pembangunan Universitas Udayana, 6(7), 1332-1363. 